\title{
A Stylistic Error Analysis of Williams' The Remains of the Last Emperor
}

\author{
Bassey Garvey Ufot \\ Department of English, University of Uyo, Uyo, Nigeria
}

\begin{abstract}
This paper is a study of the linguistic and 'editorial' errors observed in Adebayo Williams' novel, The Remains of the Last Emperor (1994). The study merges the theoretical postulations of two important fields of applied linguistics known as error analysis and stylistics, and investigates the various thematic, stylistic, structural and mechanical errors which leave the reader and ESL researcher with feelings of anguish and despair. The errors identified are classified and analysed under broad thematic/semantic, lexical, grammatical and graphological subheadings. They are then systematically parsed for their linguistic as well as literary implications for the reader. Based on a detailed appraisal of the challenges which these errors pose to linguistic and literary pedagogy, the research wonders whether it is not the case that, rather than exemplify a genuine creative impulse of the author, this novel is a prime example of the very shoddy writing characteristic of the Nigerian literary scene of the 90s. It concludes that Williams' novel is, both in content and form, exceedingly weak and pretentious.
\end{abstract}

Index Terms — error analysis, stylistics, structural, graphological, parsed, pedagogy

\section{INTRODUCTION: STYLISTICS, LANGUAGE AND THE NOVEL}

Stylistics is often defined as the study of varieties of language 'whose properties position that language in context'. This has resulted in such categories as language of advertising, law, politics, religion, an individual writer or even the language of a period in time. As Wikipedia argues:

Stylistics also attempts to establish principles capable of explaining the particular choices made by individuals and social groups in their use of language, such as socialization, the production and reception of meaning, critical discourse analysis and literary criticism. (p.1)

Language is thus central to an understanding of stylistic theory, its practical application and the criticism of literature. To secure the right response from his audience, the writer, like the speaker who uses language, must employ language in a way that is coherent, logical and acceptable. This is necessary because the relationship between the writer and his audience - which corresponds to the one between the speaker and hearer - is sacrosanct.

It is the audience which makes the author's work come alive. Sans the audience, it is fairly certain that any work of art will remain a moribund monument. Even in the portrait of social reality, the creative writer must employ language properly and effectively. This means that the text must satisfy the Hallidayan ideational, textual and interpersonal criteria of linguistic metafunctions. It must be properly constructed thus reflecting reality, competent use of language and reader interface.

In an age of renewed focus on reader response, what has been said above necessarily determines the way this response is obtained. Speaking about the centrality of linguistic competence to creativity, Ngara (1982, p.24) observes as follows:

Language is a very important component of the verbal arts. To be able to write effectively and artistically, the writer himself must have achieved a high degree of competence in his chosen language. This competence can only be demonstrated by his ability to mould the chosen dialect into a fit medium of artistic creation....The first requirement is that he should be at home with the language so that whatever linguistic devices he employs in his work, whether simple deviations from the norms or translations from another language, are in the final analysis products of a genuine artistic concern, not a reflection of the author's inability to handle the language effectively. Lack of proficiency in the chosen language limits the choices open to the writer and can often lead to artificiality, monotony and mediocrity.

The excuse of experimentation or second language challenge then becomes invalid and hollow when even a celebrated novel demonstrates unpardonable and inexplicable abuse of linguistic forms, structures and meaning. Readers are challenged unnecessarily and alienated, and their response is further compromised. As Ngara states, 'the reader's response will depend on...the nature of the utterance, what the author says and how he says it...' (p.14). Although Ngara cites the reader's own competence, experience and the usefulness of his method/approach as other reader-response variables, it is clear that the author's competence is crucial to the success of reader-response.

Stylistics is thus well placed to act not just as a bridge between literary creativity and linguistic code but also as an investigative agent over the propriety in the use of this code. The goals of stylistics in this regard are enumerated by Ngara as follows: 
[The stylistician] must use the analytic tools of the linguist...; he must to some degree concern himself with minute details of grammar, lexis, phonology, prosody, meaning, as well as with the wider issues of deviation from the norm, the relationship between language and character, the relationship between the author and his audience.... Like the conventional critic he is interested in theme, plot and character, except that his interest is always related to the role that language plays in the delineation of these features of the novel (p.12).

Thus, whatever the technique of the writer, whatever his method of handling language registers, the stylistic critic must judge the appropriateness and effectiveness of the author's linguistic choices (Ngara, 1982, p.25).

The work of the stylistic analyst that this research advocates is one which judges the success of the writer's wrapping technique in relation to the value of the article in the parcel, for, the wrapping technique and the value of the article are of equal importance. It is therefore prescriptive and descriptive. Leech (2008, p.3) refers to the importance and inextricability of the formal and functional aspects of literary and textual study in the following words:

This interface between linguistic description and interpretation is precisely the sphere of stylistics as I see it: by undertaking a linguistic analysis as part of the interrelation between the two fields of study, we facilitate and anticipate an interpretative (evaluative) synthesis. Within stylistics, that is, linguistic and literary concerns are as inseparably associated as are the two sides of a coin.

As observed above, although stylistics as a study has always been descriptive, eschewing prescriptive tendencies, the kind of stylistics advocated here combines both. The technique of this kind of stylistics is as much about revealing the salient features of a text from linguistic insights as it is about making value judgments about the effectiveness, validity and contextual acceptability of these features. It is a stylistic error analysis. Stylistics can do no less. This essentially broader view of the relationship between stylistics and the language of an author is validated by Simpson (2007, p.3) when he says:

It is the full gamut of the system of language that makes all aspects of a writer's craft relevant in stylistic analysis. Moreover, stylistics is interested in language as a function of texts in context, and it acknowledges that utterances (literary or otherwise) are produced in a time, a place, and in a cultural and cognitive context. These 'extra-linguistic' parameters are inextricably tied up with the way a text 'means'. The more complete and context-sensitive the description of language, then the fuller the stylistic analysis that accrues.

To underscore the above postulation, this research adverts to the views of Oluikpe $(1979, \mathrm{p} .49)$ in which he suggests that 'to produce an impeccable prose, two things are necessary - grammar and stylistics'. Oluikpe, advocating accent on the pedagogical view of stylistics, proceeds to link it closely with knowledge of grammar in the following way:

In addition to grammar, students need lessons on stylistics. Students write poorly not just because grammar is neglected; but because stylistics is neglected. Stylistics is the art of writing. It involves 'the selection of words and constructions, the length of sentences and their complexities, and the organization of the total expression'. When for instance, people complain that university students are poor writers, they mean...that the writing of students is ill organized, wordy, vague, and monotonous....Organization, wordiness, vagueness, and monotony are the province of style. And these are what are neglected in the teaching process. Consequently, students write poorly (p.51).

In advocating this role of 'linguistic police' for stylistics, Oluikpe's focus is on the linguistic competence of university students. However, these strictures can, and do indeed, apply also to errors made by creative writers in the English language from whom these students are supposed to enhance their linguistic skills. Their competence is further set back by such innumerable stylistic and grammatical errors which obscure the contextual relevance of Adebayo Williams' novel, The Remains of the Last Emperor (The Remains). We have already observed elsewhere that grammatical propriety in the use of English by writers has long been the concern of a good many scholars particular the Augustan Puritans such as Bishop Lowth, Jonathan Swift, John Dryden, Alexander Pope as well as Doctor Johnson (Ufot 2006, p.79). This is still a concern of many in stylistics. Thus, on account of the errors in The Remains, stylistics partners the theoretical and practical positions of error analysis in order to produce a robust criticism of text.

\section{ERROR ANALYSIS AND STYLISTICS}

Error analysis (EA) is a technique of applied linguistics which developed from the weaknesses of contrastive analysis (CA). CA itself is based on the theory that languages are different in structure and that these differences account for the problems the learner encounters as he seeks to learn another language (target language). CA therefore involves a detailed comparison between the structures of the learner's first language and the target language in order to determine and predict the problems which are likely to be encountered in the target language by the learner. However, CA alone has been found to be ineffective. It is incapable of accounting for all the errors encountered by the learners. Headbloom (1979, p.28) points out that:

Proponents of error analysis say that a contrastive analysis takes far too much time to conduct, and yields poor results. It predicts some problems which in effect never show up in the learner's production, while failing to predict other errors which actually do occur.... The use of error analysis comes from a rationalist theory of language learning....

An error is a systematic deviation from the acceptable forms of the language by the native or non native speaker/writer. Matthews (2007, p.126) sees error analysis as 'the analysis, for practical but also potentially for scientific ends, of errors made by students learning another language.' Also, Headbloom defines it as 'aposteriori contrastive analysis' and argues that: 
It is indeed an after the fact analysis. The focus of error analysis lies with the second language learners' errors in trying to produce the target language. The errors made are analysed and classified to see if there is any commonality among them. If the cause of the errors can be explained, we can adapt this information to our second language pedagogy (p.27).

Thus, the pedagogical view of stylistics is well suited to the theoretical and practical goals of error analysis, and both in turn are appropriate in serving as a watchdog over literary 'excesses'. On his part, Ibitoye (2004, p.251) has this to say:

Error analysis refers to the systematic study of learners' errors. Errors are systematic performance problems which the learner on his own is probably not even aware of and certainly cannot correct on his own unlike mistakes which he may realize and then correct.

Ibitoye proceeds to proffer procedures employed in error analysis as well as methods for classifying them. These include:

i) pre-systematic errors; ii) systematic errors; and iii) post-systematic errors.

Like Headbloom above, he also suggests that error analysis is to be preferred to contrastive analysis. He says:

Applied linguists who use error analysis see CA basically as only the first and necessary step in explaining why learners commit errors. Hence some doubt the value of merely predicting errors where direct observation of difficulties can be made. So, they say it is better to confront the real problem face to face....Thus, error analysis is to be preferred because it focuses on actual errors made by learners (pp.251-251).

The errors observed in The Remains belong largely to the third category of errors above which Ibitoye describes as an infrequent kind of error. This is because, as he points out, the learner has mastered the language to the extent that he can himself detect and correct his errors, yet the errors still occur.

Anasiudu (1996, p.132) identifies the significant difference between CA and EA in the following way:

The result of the failure of CA to account for all the learner's errors led to the development of the technique of error analysis. The main difference between CA and EA is that while CA is predictive EA is diagnostic. That is, unlike CA, EA requires an analysis of the learner's production to discover the errors.

Osisanwo (1996, p.142) defines an error as 'a linguistic deviation... a linguistic or paralinguistic deviation from an acceptable norm of usage'. Errors then, it must be pointed out, do not occur only at the level of grammar and orthography but also at the level of style. Stylistic errors, according to Anasiudu, are 'grammatically correct but inappropriate use of expressions' (p.135). In a creative work such as the novel this also includes thematic illogicalities, weak handling of plot, structure and denouement, grotesque grammatical constructions, a hectic preference for hackneyed expressions (journalese and offficialese) as well as shoddy spelling and punctuation.

Wales (1997, p.435) suggests that "for some people style has evaluative connotations: style can be "good" or "bad"'. Thus, stylistics as the study of a writer's style in this sense must be seen as a companion of error analysis. For, as has been observed earlier of Oluikpe's position on stylistics, the theoretical considerations of error analysis so far focus disproportionately on students' errors. There is however fairly credible evidence of learner errors in creative writing which has often been overlooked. Therefore, both sub disciplines complement each other in the continuing search for a more systematic approach to the study of the language of literature. It is an approach to style study which is better placed to conduct a thorough enquiry into the linguistic and contextual ethos of a text like The Remains.

Admittedly, the foundations of some of the errors observed in the text can be traced ultimately to the second language situation of the author as a Nigerian. Language, it has been argued, is acquired, not inherited resulting inevitably in imperfections. The English language, like any other language in Nigeria, is learnt, though not as a first language but as a second language. According to Osisanwo (1996, p.142):

Whatever is learnt or acquired can hardly be totally perfect. English, like many other human languages, is learnt. In Nigeria it is learnt not as a mother tongue, or first language, but as a second language. If native speakers of English encounter some difficulties in acquiring it, and thus exhibit errors... one can hardly expect total perfection on the part of second language learners of the language.

As some of these scholars contend, a good many of the errors are due not only to ignorance of the rules but also to carelessness, thoughtlessness and exuberant haste. For the creative writer, this is the haste to publish for personal aggrandizement rather than a genuine inspiration to contribute to literary scholarship. Let us exemplify our contentions with the text of The Remains.

\section{The PRoblem WiTh THE TEXT}

To read Williams' The Remains is to experience a feeling of intense anguish, disgust and then, despair. These negative feelings arise not from the tale itself, which, in the opinion of this study, is illogical and chimerical, but from a lethal combination of stylistic errors, unacceptable grammar and mechanics as well as negligent 'editorial' work. As a columnist for a number of weekly news magazines most notably the now defunct African Concord (Nigeria), Williams was famous for writing prose often seen as delectable albeit overly sensational sometimes. This perhaps may account for the problem of this first novel of his. It appears that the author - in his haste to produce his first full novel -unconsciously overlooks the difference between the stylistic demands of journalese and those of the more serious creative endeavour such as a novel. It is one thing to be famous for writing sensationally delightful prose in magazines 
often dwelling largely on cheap political discourse, but it is another matter entirely to convert this into a properly emotionally distilled novel in both content and form.

The text of this novel is vitiated by weak handling of the thematic and lexical framework, perfunctory grammar, unacceptable spelling and punctuation, as well as an overall careless 'editorial' work. The concern of this paper at this point is to highlight, categorize and analyse those aspects of these errors which are likely to present formidable obstacles to the linguistic competence of undergraduate students of English, who have to grapple with this novel for their course requirements. These defects are categorized broadly into thematic/semantic, lexical, grammatical and graphological errors.

\section{Thematic/SEMANTIC ILlOGiCALITIES}

A novel is an extended work of prose fiction which deals with character, action and thought in the form of a story, employing language imaginatively but accurately and effectively to educate and entertain. Palmer (1986, p.1) defines it as 'a coherent, unified, fictitious prose narrative with a beginning, a middle and an end'. Similarly, The Oxford Dictionary sees it as: 'a fictitious prose narrative of considerable length in which characters and acts representative of the real life of past and present times are portrayed in a plot of more or less complexity'. On her part, Ezeigbo (1998, p.2), while distinguishing the novel from other sub genres of fiction or prose narratives, emphasizes that the novel is 'a full and authenticated genre by which human experience is related,' and that it 'evinces an extended format, a greater variety of characters, a greater complication of plot and a more rigorous delineation of character and exploration of motives'.

The operative words in the quotations above are 'coherent', 'unified', 'the real life', 'authenticated' and 'rigorous'. All these qualities are absent in the handling of the thematic structure of The Remains. In this novel, Williams attempts unsuccessfully to explore the socialist question of class upheavals and revolution. The story revolves round a group of 'lunatics' who are led by a man simply referred to as 'the Leader'. These 'lunatics', who are really dissidents, we are told, capitalize on the social discontent in the land occasioned by Emperor Samusangudu's highhandedness, repression and tyranny to rebel against him. This results in what Williams calls 'the bloody resolution of an epochal impasse' (p.208). Thematically, however, this novel bites off more than it can possibly chew, and this results predictably in stylothematic pretensions and failure.

The story, for instance, from chapter four, is told in the first person by a man called Sir Dandy Alasika. Alasika himself was supposed to have witnessed the upheavals, indeed took active part in them, which culminated in the toppling of the Emperor and his annihilation by his own monstrous pet, a boa constrictor. Alasika now chronicles the events for posterity. In its capacity to stretch credulity too far, the narrative, reminiscent of childish fables which are inferior even to ancient Greek legends, employs obviously exaggerated vitriol to describe the Emperor without providing any clear or rigorous evidence of the Emperor's malfeasance. In terms of reader response, this paper believes that rather than identifying with this kind of narrative, the reader is, in fact, amused and must view the Emperor with some empathy.

The crimes of the Emperor are nebulously and half-heartedly described. All the reader is told in passing is that the Emperor sited the country's biggest prison-yard in the province of his bitterest political opponents. Then, the reader is inundated with the usual lazy clichés about the compulsive obsession of absolute rulers. This includes third party hearsay about the Emperor eliminating his critics by either murdering them or bundling them into a lunatic asylum on trumped up charges of insanity. But no rigorously credible examples are provided to enable the reader to form a coherent, logical and informed opinion on the Emperor's culpability. The narrator, the reader is told, had been a famous musician until he took to political satire. Yet there is no example of such satire. He and his wife were forced to separate on account of irreconcilable differences. Before the separation however, she had had a beautiful daughter for him, but she left with the daughter.

Years later, we are told, his envious friends goaded him into wooing another woman in another part of the country while he was on tour. He did and married her. But it turned out - only after she had had a son for him - that she was his own daughter from his estranged wife. This incest, emphasized by the fact that he was now bizarrely the father and grandfather of the same boy, and father and husband of the same girl, was exploited by his enemies to calumnize him and effectively end his singing career. His estranged wife committed suicide; he attempted the same but failed. He finally became insane, or was suspected of insanity, and was committed to the lunatic asylum where he met the other 'lunatics'.

The major problem here is that it is not clear whether the Emperor was one of the enemies seeking to destroy Sir Dandy Alasika. This is because we are later told by the doctor's father that the Emperor only spared Sir Dandy's life because he (the Emperor) was a fan of his musical talents. He says:

The Emperor used to steal in to watch you perform. He was a great fan of yours, and that is why you are still alive. He didn't like the way you were recruited by his opponents to abuse him. He set you up knowing you are a great donkey and that your thing does not know any boundary (p.97).

This stretches the imagination too far. There are loopholes in this line of reasoning. If the Emperor was such an admirer of Sir Dandy Alasika's musical talents why would he set about trying to ruin those same talents by setting their owner up for destruction? Was the Emperor a fan of the very same satirical songs which were 'recruited by his 
opponents to abuse him'? Did the Emperor talk Alasika into wooing and marrying a woman who turned out to be his own daughter? Did he also ensure that Alasika would never get to know the truth until after the incestuous marriage had produced an offspring? These questions are not answered by the novel, and that accounts for the feeling of contempt at these lies. The reader struggles unsuccessfully to unravel the plethora of thematic illogicalities and inconsistencies in the text. And they are more of these.

At the beginning of part two, precisely chapter nine, the author, perhaps to remind the reader that the narrative here is undertaken by the old man, Sir Dandy Alasika, says: 'A huge crowd had gathered round, listening attentively to the old man's strange tale'(p.70). Presently, on the same page, this same attentive crowd is described as cynical and apathetic, surging forward in 'disbelieving awe' (p.70). Yet a little later, the same cynical and apathetic crowd increases dramatically nodding in 'awe and bewilderment' (p.90). Can a crowd that is 'listening attentively' be 'cynical and apathetic', surge forward in 'disbelieving awe' and nod in 'awe and bewilderment' all at once? The choice of expressions here in relation to their stylistic co-text is apparently inaccurate and ineffective.

As the events reach a crisis point at the end of the novel, the narrator and the doctor (both asylum inmates at the time) suddenly acquire magical powers of invisibility. With this, they gain access to the Imperial Palace and observe, unseen, the final proceedings in the reign of the Emperor. It is here, the novel tells the reader, that they observe from close quarters what is referred to by the narrator as 'The Day of the Boa Constrictor'. The Liberation building to which the citizens have laid siege is blown up resulting in multiple deaths. The Emperor is swallowed up by his pet snake, the boa constrictor, to which he has been feeding live babies.

The narrator's powers of invisibility are such that he is emboldened by revulsion against the soldiers in the Imperial Palace and strikes one of them hard in the face with all his strength. The victim of this strike only thinks of having been bitten by mosquitoes (p.190)! The narrator then senses perhaps, but mistakenly, that despite the unengaging and disengaged tenor of the discourse, the reader has been taken in by the tale. This encourages him to add that he had assaulted the Imperial Palace 'from the Western end where there was a giant statue of the Emperor...' with his bare hands (p.199). Significantly, since there has been no prior mention of the narrator's being in possession of any arms, we must assume 'bare hands' to be case. Yet the reader is not told the outcome of this decision to assault with bare hands a place crawling with armed soldiers!

Another aspect of the thematic weaknesses of the text is in the brazen and inelegant appropriation of famous lines from some of the works of Wole Soyinka, Ayi Kwei Armah and Chinua Achebe without specifically acknowledging them. This creates disjointed and dishonest echoes of those works. For instance, before the old man begins his narrative, he conjures 'an immaculate white cock' and wrings apart its head from its body. The ritual spectacle is described as follows:

As the headless body spun round in a demented spiral, a hot fountain of blood traced a bold trajectory in the air before spraying the young man with its gory contents (p.4).

But these lines invariably echo Soyinka's description of the ritual at the funeral scene at which the late Custodian of the Grain lies in state in Season of Anomy (SOA pp.14-16). Williams, who had in an article entitled: 'Advertisement for My Style' in Tell Magazine (Nigeria) (April, 1996) subtly canvassed the gratuitous view that someone had wondered whether he was another Soyinka, copies not just Soyinka's thematic concerns but also his motifs. As a result, Soyinka's 'Custodian of the Grain' in the above novel becomes in Williams' The Remains, 'custodian of the truth' (p.12) and 'custodian of a noble heritage' (p.22). Soyinka's cocoa motif in SOA is lifted by Williams so that we now have '...sweaty men on huge fields of fresh cocao [sic] pods' (p.93).

We see further evidence of this unabashed attempt to imitate Soyinka in the conversation in the lunatic asylum in which Jerry declares: 'You seem to be genuinely afraid of bloodletting. But no society can be purified without some bloodshed' (p.108). This echoes Soyinka's statement in SOA that '...the sowing of any idea these days can no longer take place without accepting the need to protect the young seedling, even by violent means' (p.23), and his opinion in The Man Died about the January 1966 killings (in Nigeria) that '...it is the rare and lucky revolution which manages to avoid blood' (p.149).

From Armah's The Beautyful Ones Are Not Yet Born, Williams appropriates motifs of human waste (p.1), and stark nudity. Those readers who are familiar with Armah's novel will not fail to recall the description of the teacher in that novel when they read this statement in Williams' novel: 'There was the old man, completely naked'(p.95). Other instances of lexico-semantic copying can be seen in 'Sir William Winterbottom'(p.102) from Achebe's Arrow of God, and also the surfeit of cacophonous proverbs which are largely imitative of Achebe's novels, particularly Things Fall Apart. Also, surely, lightning usually precedes thunder rather than the other way round as we see in the following description in The Remains: 'A crackling thunder shattered the peace of the night. The lightning that followed blazed a fiery trail through the forest like an enemy tracer bullet' (p.9). But this is clearly illogical. Collins English Dictionary has this to say about thunder: 'A loud cracking or deep rumbling noise caused by the rapid expansion of atmospheric gases which are suddenly heated by lightning. Thus, lightning does not follow thunder. It precedes it.

For the reader then, these thematic and semantic flaws contradict the extravagant description of this novel by the back cover blurb as '... haunting, intensely lyrical... a memorable portrait...a spellbinding narrative...'. On the contrary, the dominant impression that these blunders leave the reader with can be described quite simply with the 
adjective, 'soporific' -- a word which is characteristically misspelt in the novel as 'sopoforic'(p.193). Thematically, this novel literally sends the reader to sleep.

\section{LeXICAL BLEMISHES}

There is a myriad of clearly inelegant lexical solecisms and non standard expressions which serve no stylistic purpose whatsoever. These include:

1. *floodings (p.8)

2. *cross purpose (p.8)

3. *cross firing (p.9)

4. *mildy (p.9)

5. *a honour (p.12)

6. *torturing labyrinth (p.16)

7. *in flying colours (p.47)

8. *specie (p.49)

9. *Christian (pp.51, 142,163)

10. *incidence (pp.59, 61)

11. *fanatics (p.71)

12. *alright (p.80)

13. *rhetorics (p.107)

14. *instance (p.108)

15. *an hyena-like (p.126)

16. *a luggage (p.134)

17. *damages (p.165)

18. *traditional battle dresses (p.169)

19. *waken from... (pp.169,207)

20. *knowing fully well (pp.174, 186)

21. *multi-storey buildings (p.177)

22. *...mind wondered to ... (p.186)

23. *at who (p.199)

24. *broken English (p.216)

floods

- cross purposes

-- $\quad$ cross fire

-- mildly

-- an honour

-- $\quad$ tortuous labyrinth

-- $\quad$ with flying colours

-- $\quad$ species

-- $\quad$ christen

-- incident

-- lunatics

-- all right

-- rhetoric

-- instant

-- a hyena-like

-- luggage

-- damage

-- $\quad$ traditional battle dress

-- wakened/awaked/waking from...

-- $\quad$ knowing full well

-- multi-storeyed buildings

-- $\quad$...mind wandered to...

-- at whom

The majority of these errors result from a combination of carelessness, journalistic exuberance and mother tongue interference. Surely, expressions such as 'floodings', 'crossfiring' and 'torturing labyrinth' can only lead the reader away from linguistic propriety. What stylistic purpose can this absent-minded preference for the present participle (gerundial) phrases serve? As perhaps deviant attention-getters, they fail woefully. Major dictionaries such as Collins English Dictionary, Oxford Advanced Learners Dictionary and BBC English Dictionary list the words as follows:

flood (noun): an inundation or overflowing of water.

cross fire (noun): a lively exchange of fire, ideas, opinions from two or more different places which passes through the same spot.

tortuous/torturous or torturesome (from torture) (adjective):

twisted or winding; devious or cunning; intricate; not simple; complicated; causing mental agony.

At no point in any of these dictionaries are expressions or derivations such as 'floodings', 'cross firing' and 'torturing'(as a modifier) listed. Thus, they serve no stylistic value. The same observation can be made about the expression 'mildy' which is employed by Williams in the sentence:

He reserved a mildy sinister smile for....

The suspicion of this researcher is that this error is perhaps due to the 'printer's devil' for the adverb, 'mildly', intended as a downtoner (Quirk and Greenbaum,1973, pp.131-132) for the adjective, 'sinister'. Whatever may be the case, the resulting expression is cacophonous. The errors involving 'a honour' and 'an hyena-like' are obviously the result of mother-tongue interference. Williams' native Yoruba language very often creates difficulties for some Yoruba speakers of English in their pronunciation of stressed vowel phonemes at syllable-initial positions. The common practice is for many a Yoruba speaker of English to insert the glottal fricative $/ \mathrm{h} / \mathrm{before}$ such vowels or drop it when it should be pronounced. This is corroborated by Jowitt(2000, p.79), and it often results in absurd pronunciation of 'eat'/i:t/ as 'heat'/hi:t/ and vice versa. Thus 'a honour' is the unconscious result of the author inserting /h/ in the pronunciation of 'honour' whereas 'an hyena-like' proceeds from dropping it. Jowitt argues that 'such an omission [or intrusion] of the syllable-initial $/ \mathrm{h} /$ is a salient marker of uneducated speech'(p.79).

The error in 7 involves unidiomatic use of preposition in the expression '... flying colours'. The appropriate preposition which precedes this idiom is 'with', not 'in', which obviously results from a literal interpretation of the expression. The three dictionaries cited above respectively exemplify the expression thus:

a) He passed his test with flying colours (p.561).

b) She passed the exam with flying colours (p.573).

c) Mr. Chirac will have to pass that test with flying colours (p.218). 
Error number 8 is the result of false analogy with plural forms of regular nouns. The word 'species', normally attested for both singular and plural, is incorrectly made to lose its 's' in the mistaken belief that it is the singular form of 'species' when he says 'a dreaded specie of mushroom'. The word 'specie' is a rare (archaic) word for coin money as different from bullion or paper money (Collins English Dictionary). In 2, the idiom 'cross purposes', which is wrongly written as 'cross purpose', is attested in its fixed plural form(pluralia tantum).

The errors in 9, 10, 11, 12 and 22 exemplify further instances of absent-minded mix-ups which are common with several newspaper titles in Nigeria. As we have noted already, Williams is well known for contributing articles to several newspapers and magazines in Nigeria. A good many of these titles are a study in very poor English. But here again, the errors illustrate the difference between the Chomskyan concepts of competence and performance. The concepts referred to in these errors are:

9) formal or ceremonial naming

10) specific occurrence or event

11) insane people in an asylum

12) standard form, 'all right'

not religion

22) move without control to other ideas not think hard to make a determination.

Errors 13, 16, 17 and 18 exemplify the author's wrong use of non count nouns. Whereas as non count nouns, the words 'rhetoric', 'damage' (destruction) and 'dress' (clothes for either men or women) are usually not marked for plural, the word 'luggage' does not select the singular indefinite determiner 'a/an'. This non standard morpho-lexical process is also observed in errors 19, 20 and 21 in which affixes are wrongly used. In 19, the author mixes up the types of past participle suffixes /-ed/ and /-en/ in the transitive verb 'waken' producing an incomplete word, in 20, an unidiomatic ' $y$ ' suffix is added to the word 'full', and in 21 , the participial/-ed/ suffix is incorrectly omitted from the phrase 'multistoreyed'. In 23 , it is necessary to state that although the interrogative pronoun 'who' is now often preferred in informal speech, yet as the object of a preposition (considered very formal), the objective form 'whom' is considered appropriate. According to Thomson and Martinet (2002, p.72):

In formal English we use preposition + whom:....

But in ordinary English we usually move the preposition to the end of the sentence. The whom then normally changes to who....

Error 24 involves a mix-up between 'broken English' (English that is incorrect in pronunciation, grammar and vocabulary) and Pidgin English (a distinct language resulting from contact between English and one or more vernaculars) when the author says: "Wey the chain, and wey de command?" the private with the grenade asked in broken English...'. In addition to the foregoing blunders, reflexive pronouns are wrongly used for reciprocal ideas which require reciprocal pronouns so that we have 'themselves' in '...cancelling themselves (one another/each other) out' (p.9) '...the men looked at themselves (one another/each other)'(p.87) and 'ourselves' in 'We looked at ourselves (one another/each other)'(p.127).

Apart from these lexical solecisms, the text is further vitiated by an unnecessary and excessive recourse to cheap journalese. This involves very unremarkable clichés lifted from lowly Nigerian newspapers. It is appalling that a writer of Williams' calibre is unable to resist the lure of such drab and hackneyed expressions as 'yours sincerely' (pp.47,72,77); 'shikena (illiterate form of shikenan': Hausa word for 'that's it')(p.6); 'tripped' (slang for 'excited') (p.28); and 'hidden agenda' [which was common in Nigerian newspapers at the time](pp.81,140). Sometimes, the reader gets the impression that Williams' desperation for elegance and bombast leads him to open to any page in the dictionary and appropriate at random any set of highfalutin words found therein regardless of their stylistic value. An example of this is seen in the expression 'whining and whingeing'(p.200). Both words - 'whine' and 'whinge' - are listed on the same page of all major dictionaries, and, more importantly, they mean the same thing. Therefore, they constitute unnecessary repetition in the context of their use here. They are a prime illustration of stylistic tautology or pleonasm.

\section{GRAmmatical Flaws}

If there is any aspect of the text which constitutes the most formidable challenge to the reader, it is the plethora of curious syntactic constructions. These must be the result of carelessness and incompetence on the part of the writer. Let us consider the following:

[1.6.1] They met four days earlier, the old man and the younger man...(p.5).

[1.6.2] But perhaps the real drama began six days earlier(p.5).

[1.6.3] Two decades earlier a terrible calamity befell the nation...(p.8).

[1.6.4] Or did the patients who the government described as communist insurgents infiltrated into the country and blew up the building rather than surrender, as claimed by the government?(p.8).

[1.6.5] ...the aghast and terrified secretary...(p.15).

[1.6.6] It was one event I usually look forward to (p.83).

[1.6.7] ...the attendants have seen me. And yet nobody had challenged me (p.84).

[1.6.8] There is a man here who had returned some stolen goods(p.85).

[1.6.9] It looks as if Ben had invested his loot wisely after all(p.85).

[1.6.10] When I look at that, I told myself...(p.99). 
[1.6.11] He broke this off and changed into... a blue pair of trousers(p.117).

[1.6.12] I could not but help wondering...(pp.140,181,209).

[1.6.13] I could not but help wonder...(p.145).

[1.6.14] I could not but help thinking...(p.156).

[1.6.15] I then came to the conclusion that having worked very hard to see the moment come true, the great occasion proved too much for the radical priest (p.158).

[1.6.16] I could not but help applaud...(p.163).

[1.6.17] ...that cascaded from his thin mean lips (p.211).

There is at several points in the text incompetent handling of verb tenses especially in time-shift situations. This is particularly observed in the portions of the narrative which require the pluperfect (past perfect) tense which is formed by the auxiliary 'had' with a past participle lexical (main) verb. This is observed in [1.6.1], [1.6.2] and [1.6.3]. The comparative adverb 'earlier' in the three structures is the clearest indication of temporal shift which requires the past perfect tense as follows:

1.6.1 They had met four days earlier....

1.6.2 ...had begun six days earlier.

1.6.3 ...earlier a terrible calamity had befallen the nation.

The problem of weak handling of tenses is observed further in [1.6.6], [1.6.7], [1.6.8], [1.6.9] and [1.6.10]. But in these examples we are confronted by a cacophony of inconsistent tenses which ruin the cohesion of each text. In each case, the verb tense in the first of a pair of closely related clauses (or sentences in the case of [1.6.7]) contrasts sharply with that of the second in a most awkward way. This is a common feature of the writing of many Yoruba journalists and it seems to reflect the lax verb tense cohesion of Yoruba syntax(Jowitt,2000, pp.119-120). The acceptable forms of these sentences should read as follows:

1.6.6 It was one event I usually looked forward to....

1.6.7 ...the attendants have seen me. And yet nobody has challenged me....

1.6.8 There is a man here who has returned some....

1.6.9 It looks as if Ben has invested his loot....

1.6.10 When I look at that, I tell myself that....

The error in [1.6.4], in its monstrosity, again presents one of the greatest challenges to comprehension for the reader. The chief defect of the structure stems from the words 'and blew'. Consequently, one possible way of attempting to make sense of the structure, we suggest, is to delete the linker 'and', and then convert the verb 'blew' to its present tense thus:

Or did the patients who the government described as communist insurgents infiltrated into the country by a hostile neighboring country blow up the building....

Sample [1.6.5] exemplifies an error in the use of a predicative-only adjective, 'aghast', in an attributive position. The adjective 'aghast' occurs only after the predicator in a sentence as follows:

The secretary was/stared/stood aghast and terrified.

The three dictionaries already cited emphasize that this word does not occur before a noun. The errors in [1.6.11] and [1.6.17] result from faulty placement of modifiers in a complex noun phrase. In English, colour adjectives such as 'blue' usually modify the material head noun directly rather than the partitive head of the construction. Similarly, opinion adjectives such as 'mean' in the above context always occur before shape/size adjectives like 'thin' (Quirk and Greenbaum, 1973, pp.403-404). As a result, the attested structures are:

1.6.11 .... a pair of blue trousers

1.6.17 mean thin lips

Errors [1.6.12], [1.6.13], [1.6.14] and [1.6.16] stem from a very bizarre grammatical construction which consists of the faulty '...could not but help...' accompanied by the present participle (-ing) or bare infinitive verb. The acceptable from of these constructions should be rendered as: 'I could not help wondering/thinking/applauding' or 'I could not (help) but wonder/think/applaud'.

In sample [1.6.15], we see an error commonly referred to as misplaced modifier or dangling participle. This error often results from a modifier or participle which, according to Trask (2000, p.37), 'is not grammatically linked to the rest of its sentence, or at least not in an orderly manner.' Misplaced modifiers are regarded as inappropriate in serious writing because they violate the subject-attachment rule. By this rule, the absent subject of the modifier '...having worked very hard to see that moment come true...' would be interpreted inaccurately as identical to the subject of the higher clause containing it which is 'the great occasion'. Surely, it was not 'the great occasion' which 'worked hard to see that moment come true'. It was 'the radical priest'. Therefore, the sentence ought to be: 'I then came to the conclusion that having worked very hard to see that moment come true, the radical priest found the occasion too much...'.

\section{GRAPHOLOGICAL ERRORS}

Under this category, we focus attention on the errors of mechanics and orthography which in this novel consist chiefly in negligent punctuation and slip shod spelling. Again, it is worth stating that these errors are common 
characteristics of the writing of lowly Nigerian journalists, a good many of whom have very little education or are just dilettantes. Consider the following examples.

[1.7.1] In the utter meaninglessness of life, there was some kind of meaning in the unspeakable chaos of our existence, this [sic] was some order (p.71).

[1.7.2] Then there was a huge dizzying gulf (p.83).

[1.7.3] 'The monkey sweats, it is the hair that hides it,' the old wizard remarked with a mischievous twinkle...(p.96).

[1.7.4] I think it is the power that went his head [sic], it was power that corrupted him, that turned him into a monster(p.99).

[1.7.5] orangoutang (pp.102); preeminent (p.145)

[1.7.6] negro (p.102)

[1.7.7] Napoleon's Book of Fate (p.103)

[1.7.8] Blockheads who had become pin-heads, with their private anatomy doing the thinking for them, I thought to myself in disgust...(p.201).

The majority of these errors result from comma splice and sentence fragments. Greenbaum and Nelson (2009, p.208) explain this error as follows:

The general rule is that if we juxtapose sentences..., we must use a major punctuation mark. The major punctuation marks are full stops(periods), question marks, exclamation marks, colons, semicolons and dashes.... If we use a comma instead of a major punctuation mark, the resulting error is a comma splice....

We see this error in [1.7.1], [1.7.3], [1.7.4] and [1.7.8] in the insertion of commas rather than major punctuation marks between the following pairs of words:

1.7.1 ...meaning, in...

1.7.3 ...sweats, it...

1.7.4 ...head, it

1.7 .8 ...them, I...

The first of these errors is exacerbated by the numerous other commas within the construction. Therefore, the commas in question should be replaced by a full stop, a semi colon or a dash as follows:

In the utter meaninglessness of life, there was some kind of meaning. In the unspeakable...order.

The same applies to errors [1.7.3] and [1.7.4]:

The monkey sweats. It is the hair....

I think it is...head. It was power....

In error [1.7.8], the failure to use a major punctuation has rendered the construction almost like the error of misplaced modifier in which the part, 'Blockheads...them' erroneously acts as a modifier for the subject of the higher clause, 'I'. In order to have an acceptable construction, the comma here should be replaced by an exclamation mark thus:

Block-heads who had become pinheads, with their ... them! I thought to myself...

Conversely, in error [1.7.2] a comma is necessary between the adjectives 'huge' and 'dizzying' to produce: '....a huge, dizzying gulf', since both adjectives modify the word 'gulf' separately. The errors in [1.7.5] are caused by the omission of the necessary hyphens in the compounds:

'orang-outan(g)' and 'pre-eminent';

in [1.7.6], by the use of lower, rather than upper, case ' $n$ ' at the beginning of a proper noun such as 'Negro' (see the three listed dictionaries above); and in [1.7.7] by the neglect of italics for the title of a book, Book of Fate.

The second major category of graphological blemishes involves atrocious spelling. The novel is replete with them. On the very first page, the name 'Gandhi' is misspelt *'Ghandi' (p.1); 'apoplectic' is misspelt *'apopleptic'(p.47), and 'generalissimoes' is spelt *'generalismoes' (p.82). Further down, 'cocoa' or 'cacao' is misspelt *'cocao'(p.93); 'desolate' becomes *'desolute' (p.112); 'snipers' is misspelt *'snippers'(pp.117,154); 'hoodlums' is misspelt *'hooldlums'(p. 136) and 'decrepit' becomes *‘decrepicts'(p.141). Other misspelt words include 'Volkswagen' which becomes *'volkswaggen'(p.152); 'sortie' (*sorty p.164); 'panic' (*panick p.177); 'proffered' (*proferred p.193); 'damning' (*damming p.196); 'perfidious' (*perfdious p.205); 'nerve-wracking' (*nerve-wrecking p.209); 'shining' (*shinning p.211); and 'cruelty' (*cruetly pp.215,216).

\section{CONCLUSION}

It is clear that stylistics can no longer remain a passive descriptive discipline. It must judiciously combine description with effective prescription. Stylistics must go beyond asking questions about linguistic choice. It must assess, evaluate, pass judgment and positively shape the direction of language use. To do this, stylistics must incorporate the finer techniques of error analysis to help in producing more rigorous and credible creative works. Language is a tool for communicating, informing, directing, persuading, interacting, educating and entertaining. To effectively enhance these functions, the language of even fiction must be regulated.

In the ESL classroom, the goal of a stylistic error analysis will be to equip learners and researchers with the descriptive and prescriptive procedures necessary for the interpretation and evaluation of avowedly language-centred texts. As exemplified by our study here, performance is as important as competence. To ignore performance is to endorse the sort of grotesque linguistic manifestations which Williams' wayward preferences in this novel evince. In 
themes, meaning, diction, imagery, syntax and orthography, The Remains is an immense setback to the competence of the reader. In its incredibly inaccurate handling of themes/lexis, in its very poor grammatical constructions and in its unacceptable spelling and punctuation can be found the very reasons why a good many graduates of English in Nigeria are perennially linguistically incompetent. The language of this novel is the result of an incredibly weak performance and negligent self indulgence by the author and the publishers. A stylistic error analysis such as the one employed here at once identifies the components of this setback and firmly nudges the writer and publishers to clean up their acts, for, Williams' The Remains is an unacceptable violation of the basic linguistic and literary norms of the English language.

\section{REFERENCES}

[1] Anasiudu, B.N. (1996). The technique of error analysis. Ogwueleka, O.S, Babatunde, Y.A \& Osisanwo, W. Eds. Effective English usage for tertiary institutions. Lagos: Greenline Pubishers. 132-141.

[2] BBC English dictionary (1992). Harper Collins Publishers.

[3] Collins English dictionary (1985). Collins.

[4] Ezeigbo, T.A. (1998). A companion to the novel. Lagos: Vista Books.

[5] Greenbaum, S. \& Nelson, G. (2009). An introduction to English grammar. Harlow: Pearson Longman.

[6] Headbloom, A.G. (1979). Error analysis and theoretical considerations in second language learning. Ubahakwe, E. Ed. The teaching of English studies. Ibadan: Ibadan University Press. 27-45.

[7] Ibitoye, C.A. (2004). Fundamentals of applied linguistics. Bamisaye, T.O. Ed. An integrated study in language and society 1. Lagos: Majab Publishers. 235-256.

[8] Jowitt, D. (2000). Nigerian English usage Ikeja: Longman Nigeria Plc.

[9] Leech, G. (2008). Language in literature. Harlow: Pearson Longman.

[10] Matthews, P.H. (2007). The concise Oxford dictionary of linguistics. Oxford: Oxford University press.

[11] Ngara, E. (1982). Stylistic criticism and the African novel. London: Heinemann Books.

[12] Oluikpe, B.O. (1979). Can a knowledge of grammar make us better writers? Ubahakwe, E. Ed. The teaching of English studies. Ibadan: Ibadan University Press. 46-56.

[13] Osisanwo, W. (1996). Error analysis: A practical approach. Ogwueleka, O.S., Babatunde, Y.A. \& Osisanwo, W. Eds. Effective English usage for tertiary institutions. Lagos: Greenline Publishers. 142-152.

[14] Oxford Advanced Learners' Dictionary 8th edition (2010). Oxford University Press.

[15] Palmer, E. (1986). Studies on the English novel. Ibadan: African Universities Press.

[16] Quirk, R. \& Greenbaum, S. (1973). A university grammar of English. Harlow: Pearson Longman.

[17] Simpson, P. (2007). Stylistics. London and New York: Routledge.

[18] Soyinka, W. (1980). Season of anomy. London: Rex Collings.

[19] Soyinka, W. (1988). The man died. Ibadan: Spectrum Books.

[20] The Oxford English Dictionary. (1989). 2nd Edition. Oxford: Oxford University Press.

[21] Thomson, A. J. \& Martinet, A.V. (2002). A practical English grammar. Oxford: Oxford University Press.

[22] Trask, R. L. (2000). The Penguin dictionary of English grammar. London: Penguin Books Ltd.

[23] Ufot, B. (2006). Slips of the master: An error analysis of Soyinka's linguistic infelicities. English language teaching today. Vol. 5 June 2006. 77-86.

[24] Wikipedia, the free encyclopedia. Stylistic. Retrieved: 10/11/2006. http://en.wikipedia.org/wiki/stylistics-(linguistics).

[25] Williams, A. (1994). The remains of the last emperor. Ibadan: Spectrum Books Ltd.

Bassey Garvey Ufot was born in Aba, Nigeria on 22nd March, 1964. He obtained a BA (Hons) English and Literary Studies of Ondo State University, Ado Ekiti (now Ekiti State University, Ado Ekiti), Nigeria, in 1987. He also obtained an MA English in stylistics in 1992 and a PhD English in stylistics in 2004 of Ahmadu Bello University, Zaria, Nigeria.

He has taught at the University of Ado Ekiti, Nigeria, and is currently a Senior Lecturer at the University of Uyo, Nigeria, where he teaches stylistics and discourse analysis. He is also the author of the following books: 1. An Introduction to Practical Stylistics. Lagos: Solar Flares communications. 2006. 2. A Short Guide to English Phonetics and Phonology. Lagos: Solar Flares communication. 2007. 3. Modern English Structure. Uyo: Robert Minder international Ltd 2009. His research interests include stylistics, phonetics/phonology and the grammar of English.

Dr. Ufot is a member of Nigeria English Studies Association (NESA) and National Association of Teachers and Researchers of English as a Second Language (NATRESL) to which he is a consultant stylistician. 